\title{
Militarization, human rights violations and community responses as determinants of health in southeastern Myanmar: results of a cluster survey
}

\author{
William W. Davis ${ }^{1 *}$, Luke C. Mullany ${ }^{1}$, Matt Schissler², Saw Albert ${ }^{3}$ and Chris Beyrer ${ }^{1}$
}

\begin{abstract}
Background: The Myanmar army and ethnic armed groups agreed to a preliminary ceasefire in 2012, but a heavy military presence remains in southeastern Myanmar. Qualitative data suggested this militarization can result in human rights abuses in the absence of armed engagements between the parties, and that rural ethnic civilians use a variety of self-protection strategies to avoid these abuses or reduce their negative impacts. We used data from a household survey to determine prevalence of select self-protection activities and to examine exposure to armed groups, human rights violations and self-protection activities as determinants of health in southeastern Myanmar.

Methods and findings: Data collected from 463 households via a two-stage cluster survey of conflict-affected areas in eastern Myanmar in January 2012, were analyzed using logistic regression models to identify associations between exposure to state and non-state armed groups, village self-protection, human rights abuses and health outcomes. Close proximity to a military base was associated with human rights abuses (PRR 1.30, $95 \%$ Cl: 1.14-1.48), inadequate food production (PRR 1.08, $95 \%$ Cl: 1.03-1.13), inability to access health care (PRR 1.29, $95 \%$ Cl: 1.04-1.60) and diarrhea (PRR 1.15, $95 \%$ Cl: 1.05-1.27. Direct exposure to armed groups was associated with household hunger (PRR1.71, $95 \%$ Cl: 1.30-2.23). Among households that reported no human rights abuses, risk of household hunger (PRR 5.64, $95 \%$ Cl: 1.88-16.91), inadequate food production (PRR 1.95, 95 \% Cl: 1.11-3.41) and diarrhea (PRR 2.53, 95 \% Cl: 1.45-4.42) increased when neighbors' households reported experiencing human rights abuses. Households in villages that reported negotiating with the Myanmar army had lower risk of human rights violations (PRR 0.91, $95 \%$ Cl: 0.85-0.98), household hunger (PRR 0.85, $95 \%$ Cl: 0.74-0.96), inadequate food production (PRR 0.93, $95 \%$ Cl:0.89-0.98) and diarrhea (PRR 0.89, $95 \%$ Cl:0.82-0.97). Stratified analysis suggests that self-protection strategies may modify the effect of exposure to armed groups on risk of human rights violations and some health outcomes.

Conclusion: Militarization may negatively affect health in southeastern Myanmar, and village self-protection activities may reduce these impacts. As southeastern Myanmar opens to international health and development interventions, implementing agencies should consider militarization as a determinant of health and design interventions that can mediate its effects. Such interventions should take into account existing self-protection strategies, seek to provide support where possible and, at all times, take care not to unintentionally undermine them.
\end{abstract}

Keywords: Human Rights, Burma, Myanmar, Militarization, Agency, Resilience, Protection, Self-Protection, Public Health

\footnotetext{
* Correspondence: wdavis29@jhu.edu

${ }^{1}$ Center for Public Health and Human Rights, Johns Hopkins Bloomberg

School of Public Health, Baltimore, MD, USA

Full list of author information is available at the end of the article
} 


\section{Background}

Southeastern Myanmar, encompassing eastern Bago region, Mon and Karen states, and Tanintharyi Region, bordering Thailand, has for decades been made up of a patchwork of state and ethnic armed groups seeking to administer overlapping territories [1]. During 60 years of conflict in south eastern Myanmar, human rights violations have had detrimental effects on health, including direct injury, loss of food supplies, malnutrition, inability to access healthcare and loss of capital used to produce health [2-6].

In early 2012 the Government of Myanmar began agreeing to preliminary ceasefires with these groups and, though the negotiation process remains ongoing, this has resulted in a significant reduction in armed conflicts - though not a complete cessation. Reports from these areas over the last two decades, however, indicate that militarization, or the presence of the armed actors, even in the absence of armed clashes can result in human rights violations, including forced labour, capricious taxation, and land grabbing; arbitrary arrest, detention and execution; forced relocation and movement restrictions; and sexual violence [7-9]. This suggests that, even following ceasefires or the otherwise cessation of violent clashes in the region, civilians' health and human rights may still be affected by the presence of the military [10].

Southeastern Myanmar is an example of a region in which international interventions to protect civilians from conflict and armed groups have had mixed results. This is primarily because, throughout the period of armed conflict (1948-2012), international humanitarian protection actors were denied access to civilian populations. In comparison to international efforts, it has been widely recognized that local strategies to manage risks associated with conflict and militarization can be extremely effective, though they should not be taken as a substitute for parties to conflict meeting their responsibilities to respect obligations under human rights and humanitarian law. The Active Learning Network for Accountability in Practice (ALNAP) guide for humanitarian protection, for example, notes that "Humanitarian common sense affirms the value of people's own knowledge, capacity, insight and innovation in any given situation that threatens them... People are seldom passive when they feel at risk: they engage in a range of finely judged actions to cope, respond, adapt and survive" [11]. Critics also note, however, that top-down international approaches rarely incorporate civilians' management of their own risks or inform civilians how best to manage risk [12-14].

Local self-protection strategies have been welldocumented in southeastern Myanmar. Beginning in the early 2000s, local organization the Karen Human Rights Group (KHRG) also began seeking to document individual and village-level self-protection strategies and then develop interventions to strengthen the most effective approaches [8]. Building on this, the Local to Global Protection Project, began additional research on these strategies and potentials for international support [9]. These studies identified multiple effective strategies used by villagers to protect themselves both from abuse associated with clashes between armed groups (e.g., targeted attacks on civilians, indiscriminate fire) and those abuses that occur in light of militarization, particularly administration of territory by the state army rather than civilian authorities (forced labour and capricious taxation; arbitrary arrest, detention and execution; forced relocation and movement restrictions). These strategies can be organized into the three-part typology, which categorizes self-protection strategies as containing, avoiding, or confronting protection threats [15]. In southeastern Myanmar, examples of these strategies have ranged from negotiating with armed groups, fleeing the village to avoid abuse, to using homemade landmines and Gher der ("home guard" militias) to protect villages [7-9]. Strategies that are assessed by this research, which represent just a few of the self-protection activities people use, are fleeing, refusing to comply, negotiating and paying bribes to reduce goods or labor demanded by armed groups.

Following the end of a major military offensive during 2005-2008, levels of armed conflict in southeast Myanmar waned substantially, though some localized areas continued to see fighting through the end of 2011 [7, 16]. Initial ceasefires in early 2012, along with political liberalizations in the Myanmar government, have led to dramatically increased international development aid for Myanmar, including in the southeast. As previous governments in Myanmar restricted access of humanitarian groups to conflict zones, experience working in these areas is largely limited to community-based groups. Challenges for new development efforts will include understanding determinants of health unique to southeastern Myanmar, where conflict has abated yet militarization persists.

We analyzed associations between exposure to armed groups and exposure to human rights violations as predictors of low food security and poor health outcomes, and we examined self-protection strategies as modifiers of these relationships.

\section{Methods}

The data for these analyses were collected through a multistage cluster survey conducted in southeastern Myanmar in 2012 initially designed to identify household-level associations between human rights violations and health outcomes [17]. In this analysis, information collected at the household level (human rights violations, exposures to armed groups, health outcomes and community self-protection activities) was used to create village-level variables (any or no community self-protection activities), combined with data collected from village leaders (distance to military base) to examine determinants of health. We examined associations 
between militarization and human rights violations, militarization and health outcomes, human rights violations and health, and effect modification of selfprotection on these associations.

\section{Survey instrument}

The survey questionnaire comprised four modules that assessed demographics and health of household members, access to health care, food security and human rights violations. One respondent for each household answered for all individuals in the household. The first module covered age and sex distribution of household members, middle-upper arm circumference of children under five, night blindness and diarrhea (both in the two weeks prior to the survey) in all household members. The next module covered access to health care in southeast Myanmar. The third module covered food security in two sections: the six-question USAID Food and Nutrition Technical Assistance Project (FANTA) household hunger $(\mathrm{HHH})$ survey, which covered one month prior to the survey, and the months of adequate household food production (MAHFP) survey [18, 19]. Months of adequate household food production is a count of the number of months in the preceding year that the household had sufficient food. The final module covered human rights violations, exposure to armed groups and self-protection activities, all with a recall period of the year before the survey. Six responses were possible for the village self-protection question, based on what community groups said were most common and what could be most accurately captured with this survey instrument: negotiate (with armed groups for reductions in demands of goods or labor), pay (to reduce labor/goods demanded), flee (to avoid complying with demands), refuse (to comply with demands), no response and don't know.

\section{Sampling}

The sampling universe for the original survey, shown on a previously published map [17], included 80,000 adults and children living in 250 villages in clinical catchment areas served by community-based health organizations in southeastern Myanmar. Implementing partners provided population data from the areas where they worked. No major population movements were reported in these areas during the time covered by the survey. Some forced displacement did result from conflict land confiscations, and economic migration was likely ongoing, but we do not feel that these movements would significantly change the implementing partners' population figures [20].

According to sample size calculations for the original survey, we needed to approach 720 households in order to estimate with $5 \%$ precision prevalence of human rights violations on the order of $15 \%$. The calculation assumed a survey return rate of $82 \%$ (based on previous surveys in the research area) $[4,5,21-23]$ and a design effect of 3.0 (because human rights violations typically cluster within communities at higher rates than other outcomes more commonly measured in health surveys). To reach 720 households, we undertook a 90 cluster $\times 8$ household per cluster design; this many-clusters-ofsmall-size approach was followed to minimize design effect (presuming uneven distribution of outcomes across clusters), to reduce the impact on data if a surveyor lost data forms if he or she had to suddenly flee the village, to minimize the time each surveyor spent in a village (8 interviews took two days) and to balance logistical constraints of travel time between villages. In the first stage of sampling, villages were enumerated and selected randomly with probabilities proportional to each village's population. In the second stage, eight households in each village were selected randomly using the Expanded Programme on Immunisation (EPI) method, which entails locating the approximate center of the village, randomly selecting a direction, randomly selecting one house along that direction between the center and edge of the village, and sampling that house and the seven closest houses [5, 24-30].

\section{Instrument development and surveyor training}

The survey was based on a questionnaire used previously in Chin State, Myanmar [31] that was modified by local partners to accurately capture events in southeastern Myanmar [32]. The modification process involved extensive consultation with community-based human rights groups; this led to inclusion of questions that enabled us to analyze the relationships between militarization, abuses and self-protection strategies. The survey instrument was translated into Sgaw Karen and Burmese and then backtranslated to English to ensure accuracy. The survey questionnaire covered exposure to armed groups, human rights violations, distance to the nearest Myanmar army base, and self-protection activities. Six responses were possible for the village self-protection question: negotiate reduction in labor demanded, pay to reduce the labor demanded, flee to avoid forced labor, refuse to do the labor demanded, no response and don't know.

Partner community-based organizations contributed 22 surveyors (16 male, six female, 20-38 years old) who were working inside the study area, fluent in Burmese or Sgaw Karen and had extensive political and geographical knowledge of the region in which they worked. For security reasons, they were assigned clusters only in their home regions. Surveyors were trained in lectures and practice sessions on taking informed consent, the survey instrument and measuring middle-upper arm circumference (MUAC) of children under five over two weeks. They were required to pass an exam before implementing the survey. 


\section{Implementation}

Surveyors conducted the study in January 2012, and the questionnaire covered events that occurred 12 months prior to the survey, with the exception of the household hunger section (one month recall) and health status questions (two weeks recall). Surveyors first obtained consent from village leaders and asked about exposure to armed groups and health problems, then interviewed households. Participants were 18 years old or older (15 if married) living in the survey area, who spoke Burmese or Sgaw Karen, gave informed consent and were deemed by the surveyors to be psychologically competent to participate in the survey. Anyone who ate meals in the house for two months preceding the survey was included as a household member.

\section{Statistical analysis}

Only households in areas affected by conflict and militarization (everywhere but Dawei/Tavoy area in the original survey, which we assumed was non-conflict and administered by civilian authorities) were included in this secondary analysis; 463 households of the original households sampled (66.5\%) were located in conflictaffected areas and only these were included in the analysis for this paper. While the original survey was sufficient to provide approximately $5 \%$ precision around human rights violations occurring at $15 \%$ frequency, the reduced sample size available for this secondary analysis reduces that precision to approximately $6.2 \%$. Data (outcomes and exposures) were weighted at either the clinical area level or the village level by population, and all analyses were performed with STATA 13 using svy commands to apply Taylor linearization, which enables conservative estimation of variance when clusters are of different sizes (as in this case). Survey coverage and participation rates were estimated. Prevalence of human rights violations, health and nutrition outcomes, and self-protection activities were estimated and $95 \%$ confidence intervals were calculated.

The goal of the interpretive analysis was to quantify associations (numbered 1 through 10 in Fig. 1) of determinants of health and to examine self-protection as a modifier of the effects of those determinants. All interpretive analyses

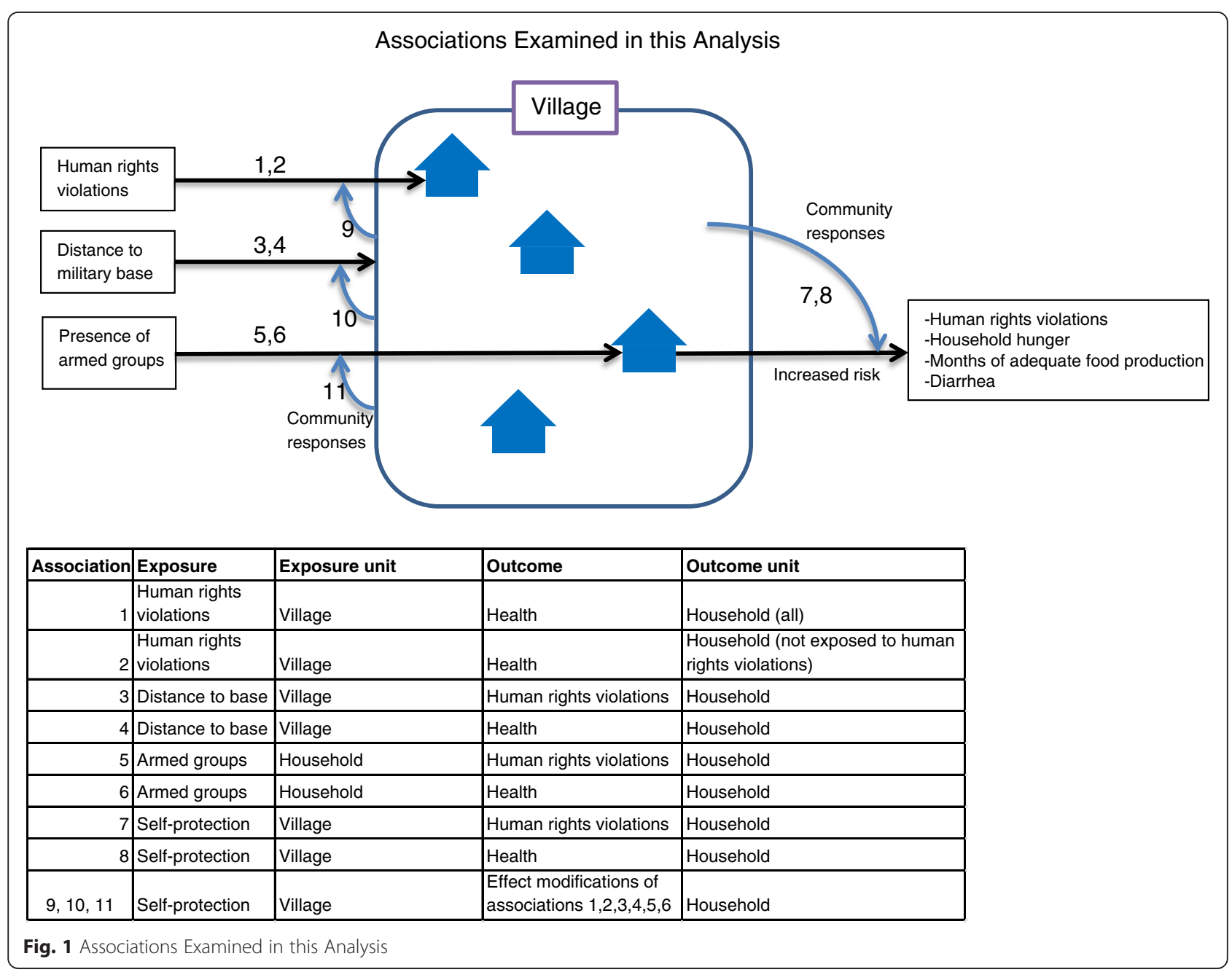


were adjusted for household size, area, type of water supply, religion, ethnicity, female-headed household and terrain (mountain or plains) using stepwise forward selection with $\mathrm{p}<0.10$ as selection criteria; unadjusted models were also done. Prevalence rate ratios between exposure to armed groups, human rights violations and health outcomes and $95 \%$ confidence intervals were estimated using generalized linear models with log link functions or Poisson regression when models did not converge. We coded household hunger (moderate/severe and none/mild), months of adequate household food production (1-9 months/ 10-12 months) and diarrhea and night blindness (present/ not present) and human rights violations (any/none) as binary variables. The months of adequate household food production cutoff of nine months best captured the difference between households that experienced human rights violations and those that did not. About $15 \%$ of the questions on selfprotection and distance to base were missing, likely because of the sensitive nature of the questions. We used listwise deletion to handle missing data.

We first investigated militarization as a risk factor for human rights violations, using distance to Myanmar military base (defined in terms of time spent walking between the location of residence and military bases; time walking was used because foot travel was the primary mode of travel and mountainous topography means linear distances are rarely referenced by populations living in the research area) or exposures (defined as seeing any armed group, seeing specific armed groups, and the total number of different armed groups seen) as predictors (associations 3 and 5, Fig. 1).

Next we examined determinants of household health. We estimated the risks of diarrhea, household hunger (HHH), being sick and not able to access treatment (sick and no tx), and nine or fewer months of adequate household food production (MAHFP) using proximity to the nearest military base or exposure to armed groups as predictors (associations 4 and 6, Fig. 1). In a subpopulation of households that did not report human rights violations, we estimated the risk of poor health if other households in the same village reported human rights violations (associations 1 and 2, Fig. 1).

Finally we investigated the effects of self-protection on human rights violations and on health. For each village sampled, we combined the responses for household selfprotection and, for the whole village, generated continuous village self-protection variables. For each village the total number of any single self-protection activity (e.g. negotiation) was between 0 and 8 , the maximum number of households surveyed in the village. According to existing research reverenced above, interactions between armed groups and civilians tend to be done at a village level, for example, armed groups will demand a certain number of porters of bags of rice from a village, and the village must decide how this burden will be distributed among households. Armed groups less frequently make specific demands of a single household. Because civilians tends to interact with armed groups as a village unit, treating selfprotection as a village-level continuous variable most accurately reflected the dynamics between armed groups and civilians in southeastern Myanmar.

We examined associations between village self-protection and exposure to armed groups, human rights violations and health outcomes all measured at the household level (associations 7, 8, 9, 10, 11 in Fig. 1). Next we stratified the dataset by village self-protection and examined associations between exposure to armed groups and outcomes of human rights violations or health. Small sample sizes precluded an analysis of interaction terms in multiple logistic regression.

This study was approved by the Institutional Review Board at Johns Hopkins Bloomberg School of Public Health, the Ethics Review Board at Physicians for Human Rights, and an ad hoc Karen community advisory team.

\section{Results and discussion}

Sampling is shown in Fig. 2. Surveyors approached 90 villages, omitted 10 because of security reasons, and substituted eight by selecting the villages closest to the insecure villages. One village leader refused to consent to the survey, and 88 villages were included in the original analysis. Of the households approached, 9 did not consent to the survey. For the sub-analysis described here, we included 551 households that were located in militarized and conflict-affected areas. We dropped 88 (16\%) households from the analysis because they refused to answer the self-protection questions, thus 463 households were included in the final analysis. This sample included 2471 people.

Health, human rights and self-protection outcomes and exposures to militarization are shown in Table 1. Of 463 households surveyed, 148 (26.8 \%, 95 \% CI: 20.4-34.2) reported experiencing at least one human rights violation, 354 (79.7 \%, 95 \% CI: 72.7-85.3) reported seeing at least one armed group, and 226 (48.7 \%, 95 \% CI: 38.4-59.3) reported engaging in at least one self-protection activity in the year prior to the survey. The distance between surveyed household and the nearest army base ranged from 1 to $30 \mathrm{~h}$ hiking.

We identified several statistically significant associations between militarization, human rights violations and poor health outcomes (Table 2). Proximity to military bases was associated with increased risk of human rights violations and poor health outcomes. For each hour of hiking closer to a Myanmar army base (relative to responding household's location), a household's risk of experiencing any human rights violation increased by $30 \%$ (1.30, 95 \% CI: 1.141.48). Similarly, risk of reporting $<10$ months of adequate 


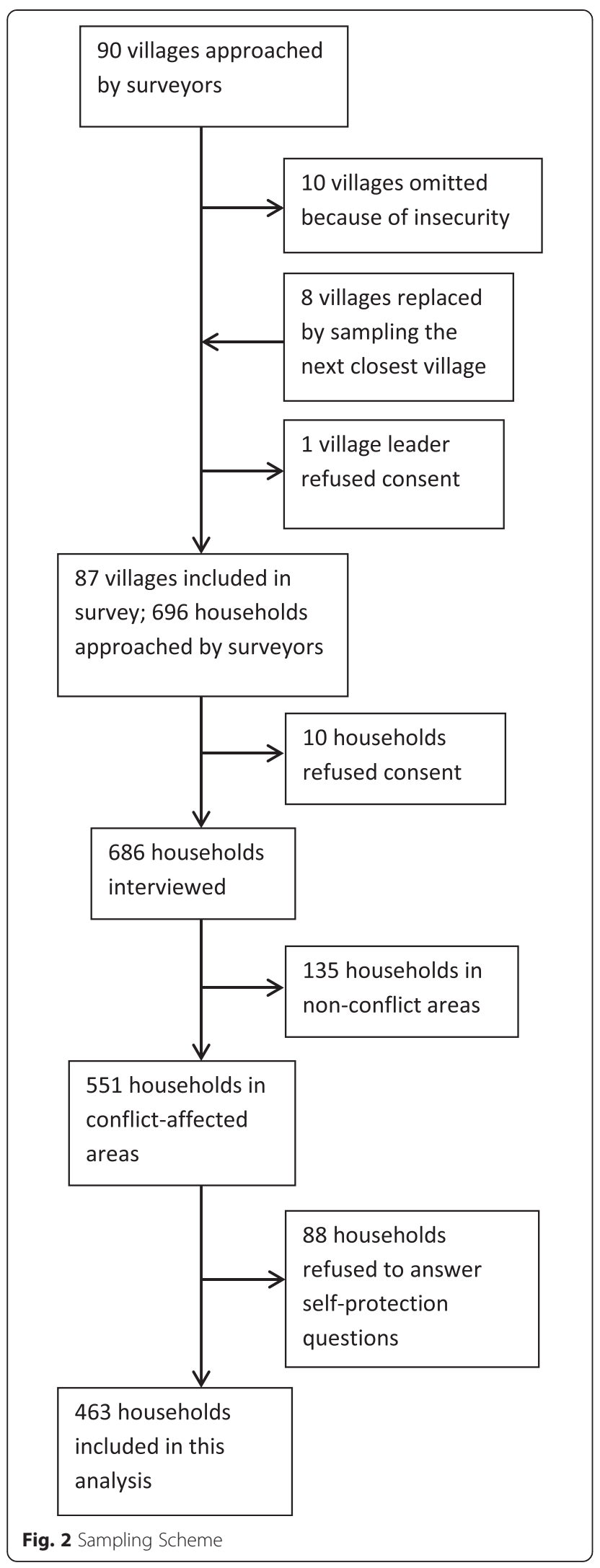

household food production increased by $8 \%(1.08,95 \% \mathrm{CI}$ : 1.03-1.13), risk of a household member being sick and not able to receive treatment increased by $29 \%$ (01.29, 95 \% CI: 1.04-1.60), and risk of a household member reporting diarrhea increased by $15 \%$ (1.15, 95 \% CI: 1.05-1.27). For each of the outcomes, design effects were calculated; these ranged from 0.8 to 2.1 .

Exposure to armed groups was also associated with increased risk of a household experiencing human rights violations and poor health: households that reported seeing Myanmar army or Border Guard Forces were 5.7 times more likely to report moderate or severe household hunger (95 \% CI: 2.5-13.0) and 12.5 times more likely to report that a household member was sick and not able to get treatment (95 \% CI: 5.06-30.69) compared with households that did not report seeing these groups (Table 2).

Human rights violations of one household were associated with increased risk of poor health in neighboring households. Among households that did not report human rights violations, having a neighbor that reported human rights violations increased the risk of household hunger and diarrhea by 5.64 (95\% CI: 1.88-16.91) and 2.53 (95 \% CI: 1.45-4.42) times, respectively, compared with households not having neighbors who reported rights violations (Additional file 1).

Of the types of self-protection assessed, village negotiation had the most statistically significant results out of all four forms assessed, and is the only type discussed here (Table 3, Additional files 1, 2, 3 and 4). Negotiation was associated with reduced risks of household hunger (PRR 0.85, $95 \%$ CI: 0.74- 0.96), reporting $<10$ months of adequate household food production (PRR 0.93, $95 \%$ CI: 0.89-0.98), diarrhea (RR 0.89, 95 \% CI: 0.82-0.97), having a household member sick and not able to access treatment (PRR 0.81, $95 \%$ CI:0.71-0.93) and reduced risk of any human rights violation (PRR 0.91, 95 \% CI: 0.85-0.98).

Furthermore, village negotiation appeared to modify the relationship between exposure to armed groups and human rights violations and health outcomes (Additional file 3). Village-level negotiation slightly weakened the associations between exposure to armed groups and experiencing any human rights violation (no negotiation PRR $1.74 .95 \% \mathrm{CI}$ : 1.21-2.51, negotiation PRR 1.66, 95 \% CI: 1.25-2.23), suggesting that risk of experiencing human rights violations might be less in villages that negotiated. The modifying effect was stronger on the relationship between exposure to armed groups and health; the greatest differences were in exposure to the number of armed groups and household hunger (no negotiation PRR 2.5395 \% CI: 1.59-4.04, negotiation PRR 1.2595 \% CI: 0.36-4.38) and exposure to any armed group and diarrhea (no negotiation PRR $5.4995 \%$ CI: 1.94-15.54, negotiation PRR 0.7095 \% CI: 0.3-1.66), suggesting that, given the same exposures to armed groups, households in villages that negotiated tended to have better 
Table 1 Summary of human rights abuses, self-protection activities and militarization measures

\begin{tabular}{|c|c|c|c|c|}
\hline Indicator & Cases & Total & Percent & $95 \% \mathrm{Cl}$ \\
\hline \multicolumn{5}{|l|}{ Human Rights Violations } \\
\hline Any household member reporting human rights violations & 148 & 463 & 26.8 & $20.4-34.2$ \\
\hline Any household member reporting forced labor & 129 & 463 & 22.1 & $16.8-28.7$ \\
\hline \multicolumn{5}{|l|}{ Health } \\
\hline Moderate/severe household hunger & 57 & 459 & 13.5 & $8.7-20.2$ \\
\hline$<10$ months of adequate household food production & 185 & 460 & 38.4 & $30.0-47.5$ \\
\hline Any household member reported sick and unable to access treatment & 58 & 458 & 11.7 & $7.4-18.1$ \\
\hline $\begin{array}{l}\text { Any member of the household reporting } \\
\text { diarrhea }\end{array}$ & 167 & 2424 & 7.9 & $5.5-11.1$ \\
\hline \multicolumn{5}{|l|}{ Self-protection } \\
\hline Negotiate & 138 & 463 & 33.2 & $24.2-43.6$ \\
\hline Pay & 129 & 463 & 22.8 & $17.1-29.6$ \\
\hline Leave & 12 & 463 & 3.4 & $1.2-9.2$ \\
\hline Refuse & 68 & 463 & 19.8 & $12.4-30.1$ \\
\hline Any & 226 & 463 & 48.7 & $38.4-59.3$ \\
\hline \multicolumn{5}{|l|}{ Armed groups seen by households } \\
\hline None & 109 & 463 & 20.3 & $14.7-27.3$ \\
\hline At least one & 354 & 463 & 79.7 & $72.7-85.3$ \\
\hline Myanmar Army & 148 & 463 & 31.2 & $23.7-41.5$ \\
\hline Myanmar Army or BGF & 179 & 463 & 35.7 & $27.2-45.2$ \\
\hline \multicolumn{5}{|l|}{ Total number of different armed groups seen by household } \\
\hline 0 & 109 & 457 & 20.4 & $14.8-27.5$ \\
\hline 1 & 194 & 457 & 48.8 & $39.1-58.6$ \\
\hline 2 & 91 & 457 & 21.6 & $14.1-31.7$ \\
\hline 3 & 51 & 457 & 7.6 & $4.6-12.2$ \\
\hline 4 & 12 & 457 & 1.5 & $0.6-4.0$ \\
\hline \multicolumn{5}{|l|}{ Distance to Army base, in hours hiking } \\
\hline 1 & 120 & 403 & 25.9 & $16.9-37.7$ \\
\hline 2 & 60 & 403 & 19.2 & $10.7-32.1$ \\
\hline 3 & 98 & 403 & 21.1 & $15.3-35.8$ \\
\hline 4 & 39 & 403 & 7.3 & $3.2-12.7$ \\
\hline 5 & 32 & 403 & 6.4 & $2.6-14.9$ \\
\hline 6 & 8 & 403 & 1 & $0.2-4.9$ \\
\hline 10 & 14 & 403 & 4.7 & $1.3-15.5$ \\
\hline 12 & 16 & 403 & 5.3 & $1.5-16.4$ \\
\hline 15 & 9 & 403 & 3.4 & $0.1-14.8$ \\
\hline 30 & 7 & 403 & 2.7 & $0.1-13.7$ \\
\hline
\end{tabular}

health outcomes than households in villages that did not negotiate. Village negotiation also modified the effect between exposure to Myanmar Army or Border Guard Forces and health, although for this exposure the effect was opposite for nine or fewer months of adequate household food production (no negotiation PRR 0.5695 \% CI: 0.35-0.90, negotiation PRR 1.26
95 \% CI: 0.73-2.18) and diarrhea (no negotiation PRR 0.9295 \% CI: 0.41-2.08, negotiation PRR 1.4795 \% CI: $0.78-2.75)$, suggesting households in villages that negotiated with Myanmar Army or Border Guard Forces had increased risk of these poor health outcomes compared with households in villages that did not negotiate, given the same exposures to these armed groups. 
Table 2 Associations between militarization, human rights violations and health

\begin{tabular}{|c|c|c|c|c|c|c|c|c|c|c|}
\hline \multirow[t]{3}{*}{ Exposures to militarization } & \multicolumn{10}{|c|}{ Health and human rights outcomes } \\
\hline & \multicolumn{3}{|c|}{$\begin{array}{l}\text { Any household member } \\
\text { reporting human rights } \\
\text { violations }\end{array}$} & \multicolumn{3}{|c|}{$\begin{array}{l}\text { No household members } \\
\text { reporting human rights } \\
\text { violations }\end{array}$} & \multicolumn{2}{|c|}{$\begin{array}{l}\text { Unadjusted } \\
\text { model }\end{array}$} & \multicolumn{2}{|c|}{ Adjusted model } \\
\hline & exposed ${ }^{1}$ & cases $^{2}$ & $\%$ & exposed $^{3}$ & cases $^{4}$ & $\%$ & PRR & $95 \% \mathrm{Cl}$ & PRR & $95 \% \mathrm{Cl}$ \\
\hline Distance to base & & & & & & & 1.3 & $1.14-1.48$ & - & - \\
\hline Saw any armed group & 354 & 133 & 37.6 & 109 & 15 & 13.8 & 3.39 & $1.53-7.55$ & $1.13^{\mathrm{a}}$ & $0.58-2.19$ \\
\hline Saw MM Army & 148 & 60 & 40.5 & 309 & 85 & 27.5 & 1.42 & $0.85-2.40$ & $1.59^{\mathrm{a}}$ & $0.92-2.75$ \\
\hline \multirow[t]{3}{*}{ Saw MM Army or BGF } & 179 & 69 & 38.5 & 278 & 76 & 27.3 & 1.41 & $0.84-2.39$ & $1.6^{\mathrm{a}}$ & $0.93-2.77$ \\
\hline & \multicolumn{3}{|c|}{$\begin{array}{l}\text { Any household member } \\
\text { reporting forced labor }\end{array}$} & \multicolumn{3}{|c|}{$\begin{array}{l}\text { No household members } \\
\text { reporting forced labor }\end{array}$} & \multicolumn{2}{|c|}{$\begin{array}{l}\text { Unadjusted } \\
\text { model }\end{array}$} & \multicolumn{2}{|c|}{ Adjusted model } \\
\hline & exposed & cases & $\%$ & exposed & cases & $\%$ & PRR & $95 \% \mathrm{Cl}$ & PRR & $95 \% \mathrm{Cl}$ \\
\hline Distance to base & & & & & & & 1.28 & $1.13-1.46$ & - & - \\
\hline Saw any armed group & 354 & 116 & 32.8 & 109 & 13 & 11.9 & 3.18 & $1.30-7.83$ & - & - \\
\hline Saw MM Army & 148 & 52 & 35.1 & 309 & 75 & 24.3 & 1.35 & $0.79-2.30$ & $1.53^{\mathrm{a}}$ & $0.86-2.72$ \\
\hline \multirow[t]{3}{*}{ Saw MM Army or BGF } & 127 & 61 & 48 & 330 & 118 & 35.8 & 1.39 & $0.81-2.38$ & $1.57^{\mathrm{a}}$ & $0.88-2.79$ \\
\hline & \multicolumn{3}{|c|}{$\begin{array}{l}\text { Moderate/Severe } \\
\text { Household Hunger }\end{array}$} & \multicolumn{3}{|c|}{ Low Household Hunger } & \multicolumn{2}{|c|}{$\begin{array}{l}\text { Unadjusted } \\
\text { model }\end{array}$} & \multicolumn{2}{|c|}{ Adjusted model } \\
\hline & exposed & cases & $\%$ & exposed & cases & $\%$ & PRR & $95 \% \mathrm{Cl}$ & PRR & $95 \% \mathrm{Cl}$ \\
\hline Distance to base & & & & & & & 1.22 & $0.99-1.49$ & - & - \\
\hline Saw any armed group & 351 & 50 & 14.2 & 108 & 7 & 6.5 & 1.86 & $0.74-4.73$ & $2.06^{\mathrm{b}}$ & $0.88-4.82$ \\
\hline Saw MM Army & 148 & 40 & 27 & 305 & 16 & 5.2 & 5.59 & $2.51-12.44$ & $6.01^{b}$ & $2.73-13.25$ \\
\hline \multirow[t]{3}{*}{ Saw MM Army or BGF } & 178 & 42 & 23.6 & 275 & 14 & 5.1 & 5.2 & $2.28-11.89$ & $5.69^{b}$ & $2.48-13.02$ \\
\hline & \multicolumn{3}{|c|}{$\begin{array}{l}<10 \text { months of adequate } \\
\text { household food production }\end{array}$} & \multicolumn{3}{|c|}{$\begin{array}{l}10-12 \text { months of adequate } \\
\text { household food production }\end{array}$} & \multicolumn{2}{|c|}{$\begin{array}{l}\text { Unadjusted } \\
\text { model }\end{array}$} & \multicolumn{2}{|c|}{ Adjusted model } \\
\hline & exposed & cases & $\%$ & exposed & cases & $\%$ & PRR & $95 \% \mathrm{Cl}$ & PRR & $95 \% \mathrm{Cl}$ \\
\hline Distance to base & & & & & & & 1.08 & $1.03-1.13$ & - & - \\
\hline Saw any armed group & 352 & 149 & 42.3 & 108 & 36 & 33.3 & 1.1 & $0.77-1.59$ & $1.32^{\mathrm{b}}$ & $0.72-2.41$ \\
\hline Saw MM Army & 147 & 51 & 34.7 & 307 & 132 & 43 & 0.72 & $0.48-1.07$ & - & - \\
\hline \multirow[t]{3}{*}{ Saw MM Army or BGF } & 178 & 60 & 33.7 & 276 & 123 & 44.6 & 0.7 & $0.46-1.05$ & $0.78^{b}$ & $0.52-1.18$ \\
\hline & \multicolumn{3}{|c|}{$\begin{array}{l}\text { Any household member reported sick } \\
\text { and unable to access treatment }\end{array}$} & \multicolumn{3}{|c|}{$\begin{array}{l}\text { No household member reported sick } \\
\text { and unable to access treatment }\end{array}$} & \multicolumn{2}{|c|}{$\begin{array}{l}\text { Unadjusted } \\
\text { model }\end{array}$} & Adjuste & ed model \\
\hline & exposed & cases & $\%$ & exposed & cases & $\%$ & PRR & $95 \% \mathrm{Cl}$ & PRR & $95 \% \mathrm{Cl}$ \\
\hline Distance to base & & & & & & & 1.29 & $1.04-1.60$ & - & - \\
\hline Saw any armed group & 349 & 53 & 15.2 & 109 & 5 & 4.6 & 3.3 & $1.09-9.91$ & $3.57^{b}$ & $1.27-10.02$ \\
\hline Saw MM Army & 147 & 44 & 29.9 & 305 & 13 & 4.3 & 8.89 & $3.91-20.15$ & $11.4^{\mathrm{b}}$ & $5.18-24.88$ \\
\hline Saw MM Army or BGF & 176 & 48 & 27.3 & 276 & 9 & 3.3 & 11.01 & $4.33-28.34$ & $12.46^{\mathrm{b}}$ & $5.06-30.69$ \\
\hline & $\begin{array}{l}\text { Any mem } \\
\text { reporting }\end{array}$ & $\begin{array}{l}\text { the ho } \\
\text { ea }\end{array}$ & & $\begin{array}{l}\text { No memb } \\
\text { reporting }\end{array}$ & $\begin{array}{l}\text { the hou } \\
\text { lea }\end{array}$ & & $\begin{array}{l}\text { Unadj } \\
\text { mode }\end{array}$ & justed & Adjuste & ed model \\
\hline & exposed & cases & $\%$ & exposed & cases & $\%$ & PRR & $95 \% \mathrm{Cl}$ & PRR & $95 \% \mathrm{Cl}$ \\
\hline Distance to base & & & & & & & 1.15 & $1.05-1.27$ & - & - \\
\hline Saw any armed group & 1847 & 140 & 7.6 & 577 & 27 & 4.7 & 1.51 & $0.80-2.84$ & - & - \\
\hline Saw MM Army & 800 & 64 & 8 & 1596 & 102 & 6.4 & 1.13 & $0.58-2.19$ & - & - \\
\hline Saw MM Army or BGF & 950 & 69 & 7.3 & 1446 & 97 & 6.7 & 1.02 & $0.54-1.90$ & $1.12^{\mathrm{b}}$ & $0.60-2.10$ \\
\hline
\end{tabular}

adjusted for mountainous terrain

badjusted for mountainous terrain, source of drinking water

"Number of households exposed to "militarization" e.g. saw any armed group

${ }^{2}$ Number of households that were exposed to militarization that also reported a human rights violation

${ }^{3}$ Number of households that were not exposed to any armed group

${ }^{4}$ Number of households not exposed to any armed group but that did report a human rights violation 
Table 3 Associations between village negotiation and human rights violations and health indicators

\begin{tabular}{lcc}
\hline & PRR & $95 \% \mathrm{Cl}$ \\
\hline $\begin{array}{l}\text { Moderate/Severe } \\
\text { Household Hunger }\end{array}$ & 0.85 & $0.74-0.96$ \\
$<10$ months of adequate \\
$\begin{array}{l}\text { household food production } \\
\begin{array}{l}\text { Any member of the household } \\
\text { reporting diarrhea }\end{array}\end{array}$ & 0.93 & $0.89-0.98$ \\
$\begin{array}{l}\text { Any household member reported } \\
\text { sick and unable to access treatment }\end{array}$ & 0.89 & $0.82-0.97$ \\
$\begin{array}{l}\text { Any household member reporting } \\
\text { human rights violations }\end{array}$ & 0.91 & $0.71-0.93$ \\
$\begin{array}{l}\text { Any household member reporting } \\
\text { forced labor }\end{array}$ & 0.92 & $0.85-0.98$ \\
\hline
\end{tabular}

All results were obtained using unadjusted models

\section{Discussion}

The data presented here extends previous research on health and human rights in eastern Myanmar. It suggests that militarization could be a determinant of health, that human rights violations experienced by one household could affect health in other households in the same village, and that actions taken by households might mitigate these effects.

Health is an effective measure for examining the results of militarization, violence and human rights violations, [33-35] and conflict is a well-documented determinant of health. It is associated with increased mortality from direct violence, but it also affects distal determinants of morbidity and mortality by limiting access to healthcare, disrupting health services, depressing the economy and creating food insecurity [36-43]. The mechanisms through which militarization in southeast Myanmar could affect health might be similar to the effects of conflict on health. That hiking time to an army base is a predictor of increased risk of human rights violations suggests that abuses by the army continue to be widespread and systematic in Karen state, despite reduced conflict.

This study suggests that human rights violations experienced by one household might affect the health of a nearby household. Several mechanisms could explain this relationship: through stifling village economic production and trade (for example, when forced labor limits household productivity), by limiting movement and thus transport of medicine, by frightening witnesses of human rights violations into hiding and limiting household productivity, or by creating burdens on households that experienced rights violations that are shared by other households through social, economic and family networks. Human rights violations in neighbors' households may also indicate a high level exposure to militarization, and the mechanisms through which militarization may affect health, such as through stifling the economy, limiting access to fields or hospitals, or suppressing the health system, may also be present.

This study confirms for the first time that self-protection strategies are widely used in this setting, which supports previously qualitative arguments that people are not 'passive victims' of conflict [11]. That civilians in southeastern Myanmar have the capacity to successfully use selfprotection suggests that international actors in the region and in other contexts should continue to explore ways to support these activities. At a minimum, international actors should take care not to unintentionally undermine or constrain the use of such strategies, as this would then have unintended negative health outcomes.

We identified several cases in which negotiation weakened the effect of militarization on poor health outcomes, and two cases in which village negotiation strengthened the association. The discrepancy might be explained by unmeasured variables, such as proximity to roads, access to aid from CBOs, other unmeasured forms of self-protection or multiple exposures to the same armed group. The effects of self-protection on health may also involve mechanisms other than influencing the actions of armed groups. Villages that engage in self-protection may be more likely to engage in health-seeking behaviors (through self-efficacy or dignity mechanisms) or have improved mental health, both of which could affect physical health. Because villagers know the context of the conflict and (usually) the personalities of local commanders and units, they may only try to negotiate with specific armed groups with which they think there is some chance of success. Finally, self-protection may function at low-dose exposures to armed groups but, at higher doses or where the needs of armed actors are overwhelming and space for negotiation ceases to exist, they may be less effective or entail negative secondary effects [7].

This research contributes quantitative data to a growing body of evidence of successful ways in which civilians reduce risk of harm in times of conflict. Previous qualitative research in southeastern Myanmar suggests that villagers manage threats by complying with demands or negotiating with armed groups, avoiding threats by fleeing and confronting threats through public advocacy and active resistance [9]. Previous research found that paying bribes to armed groups was common and usually successful, as was selecting older women village as leaders who were seen as being better able to negotiate with armed groups, and could sometimes get compensation from the army for attacks and also prevent forced relocations [9]. Villages also said that they would under-report their labor force or amount of food supplies in order to reduce the amount of food or labor demanded [9].

Other forms of negotiation, such as political activism and bearing witness, have been documented in both conflict and militarized non-conflict settings. For example, other forms of negotiation, such as political activism and 
bearing witness, were documented in women's rights groups in Afghanistan and community-based groups in Guatemala [44, 45]. In the Afghan case, community groups organized humanitarian and political activities to encourage people to resist oppression. Research found that their activities raised public awareness of oppression and resulted in stronger communities [44]. Guatemalan community groups organized health tribunals to advocate for remediation from mining companies [45].

Civilians in South Kordofan, Sudan, reported that communication with hostile forces could help to reduce the risk of attack [46]. They suggested it might increase empathy from soldiers, help soldiers to think about the consequences of their actions, or help to change the political landscape to one of peace.

Intrastate conflicts are increasingly common, and they pose new threats as civilians become displaced and access by international groups is limited or nonexistent [47]. In these situations community roles for preventing violence and reducing risks from conflict become more important [38]. As knowledge of community self-protection mechanisms increases, international actors will be better able to incorporate these mechanisms in their protection interventions [12, 46, 48]. Knowledge of specific strategies that are effective may inform the development of more successful humanitarian interventions. On the other hand, seeking to understand such strategies is important so that international actors do not unintentionally undermine civilians' efforts. Finally, even where specific strategies have not yet been identified, recognizing the existing capacities of communities seeking to protect themselves may be the most important starting point for international actors.

This research is subject to several limitations. Limitations of cluster sampling apply to this survey and have been documented in detail $[26,27,29,49]$. The results of this survey cannot be generalized to areas outside of the clinical catchment areas in Karen State where the implementing CBOs operate, as these areas were not included in the sampling frame.

Insecurity precluded assessment of ten of the preselected clusters. Systematic differences, if present, in exposures and outcomes in these villages compared with sampled villages, would likely result in an underestimation of the associations between human rights violations and health outcomes.

Sample size limited the analysis: the original survey was not powered for this analysis, and missing data was high for questions relating to self-protection activities and distance to the nearest military base. In only one village did all eight households refuse to answer any of the self-protection questions. The remainder were in 22 villages, which were concentrated in two townships (Hpa An and Hpapun). These townships had the highest proportion of households reporting seeing Myanmar army or BGF.

To further explore this, we used logistic regression to identify predictors of missing self-protection variables and found that households that had seen the Myanmar army or allied BGF (but not any armed group) were statistically less likely to respond to the question on self-protection. Missing data was not associated with health outcomes (data not shown). It is possible that people in these areas were more reluctant to answer these questions because they perceived a greater threat of reprisal from armed groups or because they wanted to keep their protection activities secret.

Qualitative data suggest that, self-protection strategies are less effective or may result in their own unintended negative consequences. If this is true, then deleting the missing data would bias the analysis towards strengthening the association between self-protection and fewer human rights violations and better health outcomes. If self-protection mechanisms continue work at high doses of exposure to armed groups, deleting the missing data would not change the parameter estimate.

The recall period for survey questions ranged from two weeks to one year, and these data are subject to recall bias. MAHFP, when broken down by month, reflected previously published data on seasonal food security trends, suggesting bias here was minimal $[32,50]$. Herlihy et. al. suggest recall bias is minimal for traumatic events [51].

Respondents who experienced human rights violations may have been more likely to recall self-protection activities if a traumatic experience helped to trigger the memory. If this was the case, the analysis of self-protection and rights violations would have been biased towards showing stronger associations between human rights violations and selfprotection.

Social desirability bias may be present if surveyors or participants felt they would benefit from exaggerating results that would make stronger advocacy. This issue was covered extensively during training and was also written into the informed consent in order to minimize this bias.

Although surveyors lived and worked in the areas they were assigned to cover, it is possible that interviewees were not comfortable discussing sensitive issues .such as health or human rights violations. Due to logistical constraints, we did not match surveyors and respondents by sex. During the informed consent process, surveyors assured respondents of anonymity and confidentiality, but it is possible that sensitive information was underreported.

We did not measure mental health or self-reported health, proximity to roads or rivers, or multiple exposures to the same armed group. These measurements may have enabled a more accurate analysis of determinants of health. 


\section{Conclusions}

The ongoing peace process in southeastern Myanmar has prompted a reduction in conflict and the best opportunity for genuine peace in six decades, and this is being accompanied by an influx of development and health interventions. The effects of militarization on health cannot be overlooked when planning or evaluating public health interventions in this area. Donors aiming to improve health in Myanmar must address the problem of militarization, and evaluations of public health interventions in southeastern Myanmar should include assessments of this and also of human rights violations. Rural ethnic villages have learned to cope with militarization, and international agencies should respect and support these community strategies when planning new programs.

\section{Additional files}

Additional file 1: Associations between health in households that did not experience human rights violations and human rights violations in neighbors' households. (XLSX $10 \mathrm{~kb}$ )

Additional file 2: Associations between village self-protection activities and risks of human rights violations and poor health. (XLSX $11 \mathrm{~kb}$ )

Additional file 3: Negotiation as a modifier of associations between exposure to armed groups and risk of poor health. (XLSX $12 \mathrm{~kb}$ )

Additional file 4: Negotiation as a modifier of associations between exposure to armed groups and risk of any household member reporting human rights violations. (XLSX $10 \mathrm{~kb}$ )

\section{Abbreviations}

ALNAP: Active Learning Network for Accountability in Practice in Humanitarian Action; BGF: Border Guard Force; FANTA: Food and Nutrition Technical Assistance; HHH: Household Hunger; KHRG: Karen Human Rights Group; MAHFP: Months of Adequate Household Food Production.

Competing interests

The authors declare that they have no competing interests.

\section{Authors' contributions}

WD, LM, MS, SA and CB contributed to study design and editing the manuscript. WD and MS contributed to writing the manuscript, WD implemented field research, WD and LM performed data analysis. All authors read and approved the final manuscript.

\section{Authors' information}

WD, LM, CB: Center for Public Health and Human Rights, Johns Hopkins Bloomberg School of Public Health, Baltimore, MD, USA; SA: Karen Human Rights Group, Mae Sot, Thailand; MS: Department of Anthropology, University of Michigan Ann Arbor, MI, USA, previously the Karen Human Rights Group.

\section{Acknowledgements}

The authors would like to thank the Karen research team for their field work and Thu Htike San and Sara Peitzmeier for their contributions to surveyor training and database construction.

\section{Author details}

${ }^{1}$ Center for Public Health and Human Rights, Johns Hopkins Bloomberg School of Public Health, Baltimore, MD, USA. ${ }^{2}$ Department of Anthropology, University of Michigan, Ann Arbor, MI, USA. ${ }^{3}$ Karen Human Rights Group, Mae Sot, Thailand.
Received: 20 February 2015 Accepted: 17 September 2015

Published online: 06 October 2015

\section{References}

1. Callahan M. Policitcal Authority in Burma's Ethnic States: Devolution, Occupation and Coexistence. In Edited by Anonymous Washington, DC: East-west Center; 2007.

2. Christensen $P$. The health-promoting family: a conceptual framework for future research. Soc Sci Med. 2004;59(2):377-87.

3. Berman P, Kendall C, Bhattacharyya K. The household production of health: integrating social science perspectives on micro-level health determinants. Soc Sci Med. 1994;38(2):205-15.

4. Mullany LC, Richards AK, Lee Cl, Suwanvanichkij V, Maung C, Mahn M, et al. Population-based survey methods to quantify associations between human rights violations and health outcomes among internally displaced persons in eastern Burma. J Epidemiol Community Health. 2007;61 (10):908-14.

5. Lee TJ, Mullany LC, Richards AK, Kuiper HK, Maung C, Beyrer C. Mortality rates in conflict zones in Karen, Karenni, and Mon states in eastern Burma. Trop Med Int Health. 2006;11(7):1119-27.

6. Mullany LC, Lee Cl, Yone L, Paw P, Oo EK, Maung C, et al. Access to essential maternal health interventions and human rights violations among vulnerable communities in eastern Burma. PLoS Med. 2008:5(12):1689-98.

7. KHRG: Self Protection Under the Strain: targeting of civilians and local responses in northern Karen state. 2010.

8. KHRG. Growing up under militarisation: abuse and agency of children in Karen state. 2008.

9. South A, Perhult Malin, Carstensen N. Conflict and Survival: self-protection in south-east Burma. 2010.

10. KHRG. Truce or Transition: trends in human rights abuses and local responses in Southeast Myanmar since the 2012 ceasefire. 2014.

11. Slim H, Bonwick A. Protection: an ALNAP Guide for Humanitarian Agencies. London, England: Overseas Development Institute; 2005.

12. Baines E, Paddon E. This is how we survived': Civilian agency and humanitarian protection. Secur Dialogue. 2012;43:231.

13. Gorur A. Community Self Protection Strategies: How Peacekeepers can Help or Harm. Washington, DC: Stimson Center; 2013.

14. South A, Harragin S: Local to Global Protection in Myanmar (Burma), Sudan, South Sudan and Zimbabwe. 2012, 72.

15. Bonwick A. Who Really Protects Civilians. Dev Pract. 2006;16:270

16. KHRG. All the information I have given you, I have faced it myself. Mae Sot, Thailand: Karen Human Rights Group; 2011.

17. Davis WW, Mullany LC, Shwe Oo EK, Richards AK, lacopino V, Beyrer C. Health and human rights in post-conflict Karen State, eastern Burma. PloS ONE, 2015: Aug 26;10(8):e0133822. doi:10.1371/journal.pone.0133822. eCollection 2015.

18. Bilinsky P, Swindale A. Months of Adequate Househol Food Provisioning (MAHFP) for Measurement of Household Food Access: Indicator Guide. 2007.

19. Deitcher M, Ballard T, Swindale A, Coates J. Introducing a Simple Method of Household Hunger for Cross-Cultural Use. Washington, DC, USA: USAID FANTA-2 Project; 2011.

20. TBC. Poverty, Displacement and Local Governance in Southeast Burma/ Myanmar. Chiang Mai, Thailand: The Border Consortium; 2013.

21. Richards AK, Smith L, Mullany LC, Lee CI, Whichard E, Banek K, et al. Prevalence of Plasmodium falciparum in active conflict areas of eastern Burma: a summary of cross-sectional data. Confl Health. 2007;1:9.

22. Parmar P, Barina C, Low S, Tun K, Mhote P, Htoo N, et al. Health and Human Rights in Eastern Myanmar after the political transition: A Population-Based Assessment Using Multistaged Household Cluster Sampling. PloS one 2015 May 13;10(5):e0121212. doi:10.1371/journal.pone.0121212. eCollection 2015.

23. Parmar PK, Benjamin-Chung J, Smith LS, Htoo SN, Laeng S, Lwin A, et al. Health and human rights in eastern Myanmar prior to political transition: a population-based assessment using multistaged household cluster sampling. BMC Int Health Human Rights. 2014;14:15. Published online May 5.

24. de Ville de Goyet C, Seaman J, Geijer U. The Management of Nutritional Emergencies in Large Populations. Geneva, Switzerland: World Health Organization; 1978.

25. Roberts L, Ngoy P, Mone C, Lubula C, Mwezse L, Zantop M, Despines M. Mortality in the Democratic Republic of Congo: Results from a Nationwide Survey. 2003. 
26. Checchi F. Estimating the number of civilian deaths from armed conflicts. Lancet. 2010;375(9711):255-7.

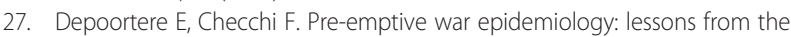
Democratic Republic of Congo. Lancet. 2006;367(9504):7-9.

28. Purdin S, Spiegel P, Mack KP, Millen J. Surveillance beyond camp settings in humanitarian emergencies: findings from the humanitarian health information management working group. Prehosp Disaster Med. 2009;24 Suppl 2:s202-5.

29. Working Group for Mortality Estimation in Emergencies. Wanted: studies on mortality estimation methods for humanitarian emergencies, suggestions for future research. Emerg Themes Epidemiol. 2007;4:9.

30. Spiegel PB, Robinson C. Large-scale "expert" mortality surveys in conflicts-concerns and recommendations. JAMA. 2010;304(5):567-8.

31. Sollom R, Richards AK, Parmar P, Mullany LC, Lian SB, lacopino V, et al. Health and human rights in Chin State, Western Burma: a population-based assessment using multistaged household cluster sampling. PLoS Med. 2011;8(2), e1001007.

32. Davis WW, Mullany LC, Shwe Oo EK, Richards AK, lacopino V, Beyrer C. Health and human rights in post-conflict Karen State, eastern Burma. PloS ONE, 2015: Aug 26:10(8):e0133822. doi:10.1371/journal.pone.0133822. eCollection 2015.

33. Pike IL, Straight B, Oesterle M, Hilton C, Lanyasunya A. Documenting the health consequences of endemic warfare in three pastoralist communities of northern Kenya: a conceptual framework. Soc Sci Med. 2010;70(1):45-52

34. Amowitz LL, Reis C, lacopino V. Maternal mortality in Herat Province, Afghanistan, in 2002: an indicator of women's human rights. JAMA. 2002;288(10):1284-91.

35. Roberts B, Felix Ocaka K, Browne J, Oyok T, Sondorp E. Factors associated with the health status of internally displaced persons in northern Uganda. J Epidemiol Community Health. 2009;63(3):227-32.

36. Bornemisza O, Ranson MK, Poletti TM, Sondorp E. Promoting health equity in conflict-affected fragile states. Soc Sci Med. 2010;70(1):80-8.

37. Coghlan B, Brennan RJ, Ngoy P, Dofara D, Otto B, Clements M, et al. Mortality in the Democratic Republic of Congo: a nationwide survey. Lancet. 2006:367(9504):44-51.

38. DeJong JT. A public health framework to translate risk factors related to political violence and war into multi-level preventive interventions. Soc Sci Med. 2010;70(1):71-9.

39. Haar RJ, Rubenstein LS. Health in fragile and post-conflict states: a review of current understanding and challenges ahead. Med Confl Surviv. 2012:28(4):289-316.

40. McDonnell SM, Bolton P, Sunderland N, Bellows B, White M, Noji E. The role of the applied epidemiologist in armed conflict. Emerg Themes Epidemiol. 2004;1(1):4.

41. Tapp C, Burkle Jr FM, Wilson K, Takaro T, Guyatt GH, Amad H, et al. Iraq War mortality estimates: a systematic review. Confl Health. 2008;2:1.

42. Zwi A, Ugalde A. Towards an epidemiology of political violence in the Third World. Soc Sci Med. 1989;28(7):633-42

43. Siriwardhana C, Wickramage K. Conflict, forced displacement and health in Sri Lanka: a review of the research landscape. Confl Health 2014, 8(1):22-1505-8-22. eCollection 2014.

44. Brodsky AE, Welsh E, Carrillo A, Talwar G, Scheibler J, Butler T. Between synergy and conflict: balancing the processes of organizational and individual resilience in an Afghan women's community. Am J Community Psychol. 2011;47(3-4):217-35.

45. Caxaj CS, Berman H, Varcoe C, Ray SL, Restoule JP. Tensions in anti-colonial research: lessons learned by collaborating with a mining-affected indigenous community. Can J Nurs Res. 2012;44(4):76-95.

46. Corbett J. Learning from the Nuba: Civilian resilience and self-protection during conflict. 2011

47. Spiegel PB, Checchi F, Colombo S, Paik E. Health-care needs of people affected by conflict: future trends and changing frameworks. Lancet. 2010;375(9711):341-5.

48. Barrs C. Preparedness Support: Helping Brace Beneficiaries, Local Staff and Partners for Violence. Arlington, VA, USA: The Cuny Center; 2010

49. Rose AM, Grais RF, Coulombier D, Ritter H. A comparison of cluster and systematic sampling methods for measuring crude mortality. Bull World Health Organ. 2006;84(4):290-6.

50. TBBC. Displacement and Poverty in Southeast Burma/ Myanmar. 201.

51. Herlihy J, Scragg P, Turner S. Discrepancies in autobiographical memories-implications for the assessment of asylum seekers: repeated interviews study. BMJ. 2002;324(7333):324-7.

\section{Submit your next manuscript to BioMed Central and take full advantage of:}

- Convenient online submission

- Thorough peer review

- No space constraints or color figure charges

- Immediate publication on acceptance

- Inclusion in PubMed, CAS, Scopus and Google Scholar

- Research which is freely available for redistribution

Submit your manuscript at www.biomedcentral.com/submit 